\title{
The Response to Individualism in Robinson Crusoe
}

\section{Applied Study to Second Year Students DENL, FEDU, Koya University}

\author{
Ahmed A. Mohammad ${ }^{1}$, Rebin A. Azeez ${ }^{2}$, Hawara N. Kareem³ \\ ${ }^{1}$ Department of English Language, Faculty of Education, Koya University, Kurdistan Region, Iraq \\ 2 Department of English Language, Faculty of Education, Koya University, Kurdistan Region, Iraq \\ ${ }^{3}$ Department of Clinical Psychology, Faculty of Science and Health, Koya University, Kurdistan Region, Iraq
}

\begin{abstract}
In this explorative study, the response to individualism in Robinson Crusoe as a character in the novel written by Daniel Defoe is scrutinized. Over 40 participants in English Language Department took role while they were studying the novel in their full academic year. In conformity with data collection, pre-test and post-test were administered on the students using individualism inventory. Their opinions in both tests were analyzed using quantitative measures. The focus of the study is to determine if students get any lessons of life from the novel namely, Crusoe's lonely life on the island, and how they are going to apply it in their own real lives on the one hand. On the other, whether or not their attitudes get affected by the individual and solitude life Crusoe experienced. That is, their psychological status and self-awareness about their individual life and community as collective. The findings confirm that students of English department on Faculty of Education were psychologically changed and have more appreciation of collective which is the community and their self-awareness as individuals. This suggests that novels provide not only knowledge chiefly related to language proficiency, but also psychological, social, and intellectual in the long run
\end{abstract}

KEY WORDS: Applied Study of Novels, Collectivism, English Novel, Individualism, Robinson Cruse

\section{INTRODUCTION}

Daniel Defoe's masterpiece Robinson Crusoe is one of the best English novels ever. The great contribution of this novel to English literature is the creation of Robinson Crusoe, this fictional character which has been regarded as the archetypal Englishman in term of politics, religion, and culture. As a cultural and social or as a life lesson for the student, it is important to remind them that Robinson Crusoe is from the Great Britain Empire in which his sense of nationality is greater than all the challenges he has faced on the island; and this lesson should be highlighted to grow the feeling of self-confidence and the sense of nationality within the student in the time of losing all the mentioned principles (Parrinder, 2006).

The greatness of Robinson Crusoe rests on its important as a first significant English novel and on its mythmaking power. Another important point about this novel and its main character is that Daniel Defoe could push his central character to the level of the archetype by adopting truthtelling resource than the fictional prototype which was common at that time. What was also a new innovation is Crusoe's physical adventure with the moral and the spiritual progress and put it in its universal pattern. The universal significance stems from the Christian pattern of

Koya University Journal of Humanities and Social Sciences (KUJHSS)

Volume 2, Issue 1, 2019

Received 14 March 2018; Accepted 03 October 2018, Regular research paper: Published 24 May 2.19

Corresponding author's e-mail: ahmed.abdulaziz@koyauniversity.org

Copyright (02.19 Dr. Ahmed A. Mohammad, Lect. Rebin A. Azeez, Asst. Lect. Hawara N. Kareem This is an open access article distributed under the Creative Commons Attribution License. - 0CC BY-NC-ND 4. 
disobedience of his parents following his ambitions. Crusoe rejected the idea of stay-at-home and ignored the providential warnings of storms at sea and temporary enslavement until he faced his ultimate punishment. What is worth to be studied and analyzed carefully is the idea of transformation from prisoner to liberated master of his domain in which the sense of individual could hardly be ignored. And the idea based on the fact of acceptance of his dependence on God's will and grace. So Crusoe reassesses his identity and accepts his limited ability and begins a new life based essential relationship of human being anticipating all the kinds of conflicts, man versus nature, man versus self, man versus God, man versus man (Burt, 2010).

\section{INDIVIDUALISM:}

Individualism according to Merriam-Webster (2018) is "a theory maintaining the political and economic independence of the individual and stressing individual initiative, action". The concept individualism goes back to 1651 when it was first used by Thomas Hobbes, the English philosopher, scientist, and historian who is known for his political philosophy in his masterpiece Leviathan (1651). John Locke is another English philosopher who dealt with the concept of individualism and shared different points with Thomas Hobbes. John Locke was an English philosopher and physician; he was one of the most influential English thinkers, he was known as the Father of Liberalism (Wikipedia, 2018). Thomas Hobbes, (born April 5, 1588, Westport, Wiltshire, England-died December 4, 1679, Hardwick Hall, Derbyshire), English philosopher, scientist, and historian, best known for his political philosophy, especially as articulated in his masterpiece Leviathan (1651) (Wikipedia, 2018).

Hobbes' Social Contract Theory dates back to 1651 during the civil war in Britain. Hobbes says that the desire to security and order is the priority of human beings' nature, for this they seek an authority to protect their live and property despite the fact that, this will lead to surrender their freedom and rights. According to Hobbes, what people were searching for led to the emergence of monarchy as the mightiest authority to meet the need of people in this sense. Hobbes supports the idea of might is right. "Law is dependent upon the sanction of the sovereign and the Government without sword are but words and of no strength to secure a man at all" (Hobbes, 1651, page 79).

Hobbes (1651) wrote his social contract theory in title Leviathan. "Leviathan is written during the English Civil War; Leviathan argues that civil peace and social unity are best achieved by the establishment of a commonwealth through social contract. Hobbes's ideal commonwealth is ruled by a sovereign power and granted absolute authority to ensure the common defense."

Thomas Hobbes is considered as one of the most remarkable individualist philosopher in the modern age. In his Leviathan (1651), (as a great organization) Hobbes attributes to all individuals his liberty and his equality as natural right and justifies all the necessary actions for the sake of protecting themselves from their fellow creatures. According to Hobbes this individual natural liberty leads to a state of chaos, conflict, and a sustain fear, this chaotic state cannot be maintained through any individual sovereign. Instead of the individual freedoms, government-imposed is required to hold all the natural freedoms except for self-preservation (Individualism Liberalism and Individualism, 2017).

On the other hand, John Locke writes in his Second Treatise of Government that the natural state is in fact a "state of perfect freedom" and a "state also of equality." Locke states that society must emulate the state of nature. So sovereignty of the state is to make the law which ensures equality and protects an individual's rights (Mouritz, 2010). Furthermore, Locke (1690) putting emphasis on private property, he says that the most important natural right which the government must protect is the right of private right. Another reason makes Locke to emphasize private property, is that man earns the right of property through his labor. Labor creates a distinction between the common and the private. Locke says that a man deserves the reward of his hard work. Private property is the result of personal responsibility, and once you have worked to gain it the government must protect it (Mouritz, 2010).

\section{INDIVIDUALISM IN ROBINSON CRUSOE:}

We need to analyze Robinson Crusoe's character as a real human being full of complexity and incoherence. Man is always regarded as an egoist and self-centered creature. Besides this negative side of human being he/ she has a positive merit which is his reason; this merit makes human being different from animals and have their own decision about his conditions of life. Both Thomas Hobbes and John Locke, seventeenth century philosophers, are known for their political philosophies on human nature and the social development. They are both concerned with the evolution of modern societies in relation to the psychology and the mind of human beings (Oztekin, 2016, 5).

Robinson Crusoe is a suitable character to be scrutinized in this respect for it contains all the features of individualism or the thoughts of the two mentioned 
philosophers. The two philosophies explain the nature of human being in the following simple way:

Hobbes says that in the state of nature, all men may have a desire to harm the others, so this greedy nature of humanity is dangerous. For him, freedom is unlimited in nature and men can do anything they regard necessary to preserve their lives. However, Locke is not as libertarian as Hobbes in this subject. Locke gives importance to the rights of the other people in spite of his defense of equality and freedom. He advises not to occupy the others' rights. His idea of self-defense is similar to Hobbes, as he mentions about the right of people to punish the invaders and rebels. According to him, men have right to prevent crimes to preserve his and the others' lives. Considering the egoism of human beings, Hobbes claims that it is not reasonable when people judge their own faults and conditions. Man's arrogance makes them biased to themselves and their situations. They cannot see their own mistakes clearly from the eyes of the others. Grant describes Locke "as a political individualist, as a kind of intellectual individualist, and an advocate of the independent use of the faculty of reason against prejudice, custom, and dogmatism (Oztekin, 2016, 2).

In addition, Daniel Defoe is closer to Locke's political philosophy. The idea is clearly noticed in Robison Crusoe in applying individualism and in the depiction of the social development from its smallest unit which is the family. Defoe believes that human being is controlled by self-interest and vanity. Defoe like Locke believes that law and government are important to provide actual freedom for human being and this political philosophy is represented through the character of Robinson Crusoe. The way of narrating the story reveals the approach of individualism; Defoe uses first-person narration to tell everything from his side, being partial of himself like other people. The absolute freedom of Robinson Crusoe just happened when he found himself alone in the isolated island with no social restrictions, no family ties or civil authorities to interfere with his individual autonomy (Watt, 1957).

This novel depicts the real relation between man and his nature, Crusoe is afraid of the natural happenings like earthquake and the storms. While he was scared of all the surrounding phenomena, he shocked by a new reason of scare, the foot print. Being scared of the foot print, the author depicts that he has been so individualist to be scared of other people; this may be the implication to show people are not fit to be solitary without people in nature, while the crowd life of human being causes people to disturb and distrust each other (Oztekin, 2016, 10).

The individualization in Robinson Crusoe is not applied just on the main character; it is also about the details of the environment surrounding him. The character of Crusoe is not just a type character like the preceded characters; we are interested in Crusoe as distinct individual with personal qualities (Hawthorn, $1986,8)$. Such ideal character, in sense of his relation with nature and with all complexities, is so important for students of the second year to inspire them and to give them an individualized lessen of life in the case of being self-independence after being under the control of the parents (Oztekin, 2016).

\section{THE PROBLEM}

One of the English department subjects for the secondyear class is novel. It is quite obvious that the study of novel gives the students the chance of practicing their reading, getting new vocabularies and expressions, and practicing an authentic and prestigious language of writing. But no one can deny the use of novel in providing lessons of live. For all these pedagogical and cultural reasons, we have to choose carefully an interesting and enjoyable novel to attract students' attention. Novels are useful for many reasons; for instance, they are enjoyable to read, they have an authentic language, they help students to study another culture, they improve students' interpretative abilities and free them from shyness obstacle to exchange opinions and feeling.

For all that, this present study is intended to survey the students' sense of individualism and collectivism out of and within their community. The research only investigated the Kurdish students studying English as a foreign language in Koya University since there is almost no study been conducted to explore the effect of novels on the students' thinking and opinions in their life.

\section{AIM AND SIGNIFICANCE}

This research project draws a bead on firstly, examining the lessons of life students get from reading the novel of Robinson Crusoe. Secondly, it also puts forward an effort to highlight the extent to which the students are psychologically affected by the theme of individualism in the sense of themselves as part of the whole community. These two aims which are the main focus in the study address the idea of students using novel in their life as a lesson, and to self-examine their status within the circle of society. Further, it also sheds light on whether the students feel the importance of the community in their life or not. That is, before reading the novel, students might not have experienced the loneliness as it was experienced by Robinson Crusoe in the island, after reading the novel; they are expected to change their thinking towards the sense of individualism and collectivism in the society. 
This study addresses state of consideration that needs to be settled. Thus, college students, EFL teachers, and linguists, and researchers in the field can get benefit from the results of the study. That is, this survey study will allow everyone to inspect and see the extent to which students are affected by the reading novels and how they apply lessons of life they get from the novel.

\section{DESIGN OF THE STUDY}

\subsection{PARTICIPANTS AND INSTRUMENTS}

The participants were students in Koya University/Faculty of Education studying English as foreign language in their second academic year. A number of 51 students participated in this study. They were divided into two groups. Two tests were administered to collect data, namely pre-test and post-test in two different intervals during the academic year of 2016 to 2017. In the data collection procedures, for both pre and post tests, the researchers used individualism and collectivism questionnaire designed by Triandis and Gelfland (1998) to measure four dimensions of individualism and collectivism, see appendix (A). First, the questionnaire was translated into participants' mother-tongue which is Kurdish language, then followed by backward translation. For the sake of validity and reliability of the scale, SPSS was used to check on 30 participants' answers. Cronbach's alpha showed (.75) which can be said it is efficiently valid and reliable since any figure above but not beneath (.60) is considered reliable.

\subsection{DATA COLLECTION AND ANALYSIS}

Data for the present study was collected using the aforementioned questionnaire in a pre-test at the beginning of the participants' study of the Robinson Crusoe Novel by Daniel Defoe (1719). Students got (the abridged) edition by (Puffin Books) in 1995. Later in the year, the post-test was conducted to collect participants' opinions after reading and studying the novel through the whole semester.

To analyze the results, the researchers used SPSS program version 17 . That is, they identified the differences in students' responses to both pre and post tests using quantitative measures.

\section{RESULTS}

In the present study, after the data collection procedures substantial amount of results worthy to be put forward. The results are classified as the following. The participants' gender in pre-test were varied and (21) of them were male. About (31) of them were females. Regarding of participants' gender in post-test were about (16) of them were male, and (29) of them were female.

Concerning the residences of the participants in pretest, (75) percent of them live in urban areas, while those who live in rural areas were about (21.2) percent. Regarding the residences of participants' in the post-test about (82.2) percent of them live in urban areas and about (17.8) of them live in rural areas. These findings are demonstrated in table (1).

TABLE 1

Demographic Data of the Study Sample

\begin{tabular}{ccccll}
\hline \hline \multicolumn{3}{r}{ Post-test } & & Pre-test & \multicolumn{2}{l}{ Demographic Variable } \\
\hline & & & & & \\
& & & & & \\
35.6 & 16 & 40.4 & 21 & Male & Gender \\
64.4 & 29 & 59.6 & 31 & Female & \\
82,2 & 37 & 75,0 & 39 & Urban areas & \\
17,8 & 8 & 21,2 & 11 & Rural area & Residence \\
& & 3,8 & 2 & Missing & \\
100 & 45 & 100 & 52 & & Total
\end{tabular}

According to THE questionnaire on horizontal, vertical individualism and collectivism by Triandis and Gelfland (1998), the items are divided into four categories. Firstly, four items are related to Horizontal Individualism. Secondly, four items are related to Vertical Individualism. Thirdly, four items are related to Horizontal Collectivism. Last items are related to the Vertical Collectivism. After analyzing the data, the Mean score of each category is compared to another.

For the pre-test sample, the horizontal individualism category Mean is higher than others (Mean=17.82) with standard deviation of $(\mathrm{SD}=2.09)$. The second higher figure is vertical collectivism category (Mean=17.90) and $(\mathrm{SD}=2.32)$. Third figure is horizontal collectivism (Mean=16.65) and $(\mathrm{SD}=2.36)$. The last figure is vertical individualism (Mean=13.86) and $(\mathrm{SD}=3.15)$, which are illustrated in table 2 .

TABLE 2

Individualism and Collectivism Mean Scores of the Pre-test

\begin{tabular}{|c|c|c|}
\hline \hline Standard Deviation (SD) & Mean & Variables \\
\hline 2.09 & 17.82 & Horizontal Individualism \\
\hline 2.32 & 17.90 & Vertical Collectivism. \\
\hline 2.36 & 16.65 & Horizontal Collectivism \\
\hline 3.15 & 13.86 & Vertical Individualism \\
\hline
\end{tabular}


For the post-test sample, the horizontal collectivism category Mean is higher than others (Mean=17.15) and with standard deviation of ( $\mathrm{SD}=1.84)$. The second higher figure is horizontal individualism category (Mean=17.53) and $(\mathrm{SD}=1.72)$. Third figure is vertical collectivism (Mean=17.64) and $(\mathrm{SD}=2.28)$. The last figure is vertical individualism (Mean=13.77) and $(\mathrm{SD}=2.92)$, these are showed in table 3.

TABLE 3

Individualism and Collectivism Mean Scores of the Post-test

\begin{tabular}{|c|r|l|}
\hline \hline Standard Deviation (SD) & Mean & \multicolumn{1}{|c|}{ Variables } \\
\hline 1.845 & 17.155 & Horizontal Collectivism \\
\hline 1.726 & 17.533 & Horizontal Individualism \\
\hline 2.287 & 17.644 & Vertical Collectivism. \\
\hline 2.922 & 13.777 & Vertical Individualism \\
\hline \hline
\end{tabular}

If we compare the mean scores of individualism and collectivism categories in pre-test with post-test scores, we can observe horizontal collectivism category in pretest coming as the third one but in the post-test it took place as the first category. Also, according to the results, vertical individualism category in the pre-test and posttest comes as the last category.

\section{DISCUSSION}

The academic committee of the English language department chose Daniel Defoe's Robinson Crusoe based on necessary facts which are related to needs of the second class students. Robinson Crusoe ranks as the first novel in the English language. This novel evokes the feeling of recognition of different senses, to savour the sense of adventure. Beside those valid reasons, this novel activates the psychological contemplation for sensitive potential emotions and behaviors. The story is based on the idea of the pragmatics of survival. It is about mastering surviving skills. And it is also about the way of coping with solitude, presenting all the psychological stages of the solitude life like loss, despair, adjustment. To feel the self is somehow an alien feeling for the department's students for they have never been independent in sense of life issues. Affecting by Crusoe's solitude, the student experienced the feeling of loneliness, and this led them to have different responses before and after reading the text. Fortunately, the students could embody the main character and experienced his feelings, and this led them to change their mind concerning the way of life which most of the time falls into individualism and collectivism.

To add more, participants' thinking have changed in terms of seeing oneself as part of the collective; being part of the larger group which is society, but perceiving all the members as equal as it is stated in the aforementioned inventory by Triandis and Gelfland (1998). For instance, before reading the novel, the students were not proud if their coworkers get a prize. Also, they chose that wellbeing of their coworkers was not important to them. In another point, to them, pleasure was not spending time with others. Further, they felt not significantly good when cooperating with others. However, after reading the novel, their opinions have changed. They were more conscious and thoughtfully in consideration of the collective and members of the society. For the sake of example, the statistical data confirmed that participants were significantly proud if their coworkers get a prize. Adding to this, they chose that well-being of their coworkers was important to them. Also, to them, pleasure was spending time with others. Finally, they felt very good when cooperating with others.

Furthermore, in the pre-test horizontal collectivism was in number three, but in the post-test after reading the novel, the sequence moved to number one. To discuss this, in our society individuals live within their families. Culturally, they both get and receive help. They can not realize how their lives would be if staying alone. But, after reading the novel, they have been obviously affected by it and realized how important others are in the community.

\section{CONCLUSION}

In conclusion, it can be stated that reading the novel of Robinson Crusoe has its own benefit for the students. This is due to the finding that their thinking has changed from the period before reading the novel to the period after reading it. The pre-test indicated that the sense of individualism and collectivism of the students seems more to be based on their ignorance to the importance of being alone and far from others in the community in order to see how important the members of the society are to one another. The post-test, however, showed that students became more aware of the collective that is the 
community and their individuality in solitude. They got the lesson that individuals need to stay in togetherness in order to sustain one's own life. They checked their own individuality as the character Robinson did when stayed in loneliness. This made them to do self-examination and approve the importance of the others in the society as collective. Finally, this can be put in the sense of lifelesson experience students have got from reading the novel.

\section{IMPLICATIONS OF THE STUDY}

In accordance to the findings and results of the research, the pedagogical implications can be collaterally worked on. This is, both teachers and students can get benefit from reading novels, particularly the ones that provide lessons of life, and pictures the importance of society, community, collectivism, individuality, and the theme of loneliness as opposed to theme of the togetherness.

The following need to be put into consideration:

- Students should read novels and be encouraged to do so in order to raise their awareness about the value of lessons of life they get after finishing the reading.

- The department of English language should continue applying the programming of the curriculum with more reading materials in literature. This will enable students to expand their knowledge about language, culture, and their own psychology.

- Psychologically, learners can be more aware of their own innermost, imaginations, feelings, and more particularly their psychology when reading life-lesson providing novels.

- Literary reading materials provide in-depth insights for students wanting to read and help them to improve their English language proficiency.

- Novels in general, capture the thinking horizon of its readers, thereby; students can generate their thinking abilities for their own good. Thus, Robinson Crusoe by Daniel Defoe is a proven example for this purpose. It is highly advised that students should read it even in their extra times.
- All the English language departments are advised to put this profitable and reader educating novel into their syllabubs. In addition, similar novels and other literary reading materials will certainly benefit language institutions, departments, and centers in shaping their learners' intellect, wisdom, thinking, and language skills that are chiefly concerned with reading and comprehension.

\section{LIMITATIONS}

The participants of this study were chosen from only one place, further study can be done in order to investigate larger scale of students in different areas. Further, the subject of the study was a novel which is selected as a syllabus for the department and is studied throughout the whole academic year; another study might explore extra curricular textbooks and literary reading materials to find out more about the inspected issue. Finally, the language study of novel in the research and in the course was in English language which is the target language of the participants. So, future research should examine the research matter by incorporating native language of the students into the research study and literary reading material.

\section{REFERENCES}

Burt, Daniel S., (2010) The Novel 100, Revised Edition. Facts on File. New York.

Defoe, Daniel. (1995). Robinson Crusoe. London: Puffin Books.

Hawthorn, Jeremy. (1986). Studying the Novel: An Introduction. New York: Routledge, Chapman and Hall.

Hobbes, Thomas. (1651). Leviathan. London. St. Pauls Church-yard, 1985.

Individualism. (Individualism - Liberalism and Individualism - Liberty, Hobbes, Natural, and Locke - JRank Articles). Retrieved online from (http://science.jrank.org/pages/9785/Individua lism-Liberalism- 
Individualism.html\#ixzz4yiaW89mZ) on 2-22018.

Locke, John (1690). Second Treatise of Government. England: Awnsham Churchill.

Merriam-Webster OD. Individualism. (2018). Retrieved online from http://www.merriam webster.com/help/faq/history.htm, on 12-012018.

Mouritz, Thomas. (2010). Comparing the Social Contracts of Hobbes and Locke, The Western Australian Jurist, Vol. 1.

Oztekin, Sercan. (2016). An Analysis of Individualism and Human Nature in Robinson Crusoe. International Journal of Humanities. Art and Social Studies (IJHAS), Vol. 1, No.1, August.
Parrinder, Patrick. (2006). Nation and Novel, The English Novel from its origins to the Present Day. Oxford: Oxford University Press.

Richetti, John. (2005). The Life of Daniel Defoe: A Critical Biography. USA: Blackwell Publishing.

Triandis, H. C. \& Gelfland, M. J. (1998). Converging measurement of horizontal and vertical individualism and collectivism. Journal of Personality and Social Psychology, 74, 118-128.

Watt, Ian. (1957). the Rise of the Novel. University of California. Berkeley, CA.

Wikipedia. John Locke. (2018). Retrieved online from https://en.wikipedia.org/wiki/John_Locke, on 14-01-2018.

\section{APPENDIX}

\section{A: Individualism and Collectivism Scale}

The questionnaire is on a 5-point scale, ranging from $1=$ never or definitely no and $5=$ always or definitely yes.

Horizontal individualism items:

1. I'd rather depend on myself than others.

2. I rely on myself most of the time; I rarely rely on others.

3. I often do "my own thing."

4. My personal identity, independent of others, is very important to me.

Vertical individualism items:

1. It is important that I do my job better than others.

2. Winning is everything.

3. Competition is the law of nature.

4. When another person does better than I do, I get tense and aroused.

Horizontal collectivism items:

1. If a coworker gets a prize, I would feel proud.

2. The well-being of my coworkers is important to me.

3 . To me, pleasure is spending time with others.

4. I feel good when I cooperate with others.

Vertical collectivism items:

1. Parents and children must stay together as much as possible.

2. It is my duty to take care of my family, even when 1 have to sacrifice what I want.

3. Family members should stick together, no matter what sacrifices are required.

4. It is important to me that I respect the decisions made by my groups.

Scoring: Each dimension's items are summed up separately to create a VC, VI, HC, and HI score. 